\title{
Tony Conner
}

Public distaste for genetically modified crops shows little sign of abating. Tony Conner thinks he's found a solution: tailor crops to be more palatable to the public.

After plenty of heated public debate, in 2002 a New Zealand Royal Commission report recommended caution regarding genetic engineering. Those voicing opinions leading up to the report's release included Greenpeace, Friends of the Earth and the Soil \& Health Association, as well as Tony Conner, a senior scientist at The New Zealand Institute for Crop \& Food Research, in Christchurch.

Those debates influenced Conner, and today he argues that public attitude will never be swayed by men in white jackets and therefore research must be tailored to the public. "You won't win those arguments by just using science," he says.

Conner's coming of age coincided with the emergence of the genetics field, and his interest in plant sciences and ecology was sparked during a summer job conducting botanical surveys for the New Zealand Forest Service. He eventually earned a BS in botany from the University of Canterbury in New Zealand in 1978 and a $\mathrm{PhD}$ in genetics from the University of California, Davis, in the US in 1985. The first transgenic plants were created in 1983, and Conner returned to New Zealand to take a position at the Crop Research division of the Department of Scientific and Industrial Research, based in Wellington, New Zealand. There, he began to apply biotechnology to asparagus, potatoes and other vegetables. He was involved in some of the first field tests of transgenic plants.

In 1992, when the New Zealand government folded its work into independent Crown Research Institutes (CRI) in Auckland, Conner joined as part of the CRI Crop \& Food Research, which is owned by the state but supports itself primarily through scientific services and out-licensing.

The increasing intensity of the Royal Commission debates coincided with Conner taking off nine months in 1999 to care for his young son, giving him an opportunity to engage in the public discussions. He soon found himself becoming a de facto defender of science. "Nobody else was standing up," he recalls. Although Conner wasn't officially representing Crop \& Food Research, they approved of his involvement, and he spent his time talking about "what we know and do not know about the science, always balanced with what we know and do not know about products from traditional breeding," he says.

Through 2000 and 2001, Conner spoke to community groups, schools and even churches, sometimes debating directly with his audiences. "I tried to tease out what their concerns were," Conner recalls. "There was often a 'yuck' factor about moving genes across species boundaries. Some perceived it as [against] God's will, and others as interfering with nature's process."

So Conner decided to roll with public opinion and shift the direction of his research. He began modifying crop plants using only DNA sequences from the same species. He labeled the approach 'intragenics', and after testing it in Arabidopsis thaliana, he moved on to potatoes. The research is distinct from cisgenics, in which species-specific genes with their natural promoters, terminators and introns are transferred between cultivars using standard vectors based on foreign DNA.

Though the technique concedes much of the power of genetic engineering by limiting the potential sources of new genes, it is a vast improvement over the trial-and-error approach of traditional breeding, which can take years of crossing and back-crossing to produce a new commercial variety. The technique would be particularly useful for crops that are propagated vegetatively, such as potatoes, fruit trees, cassava and sugarcane.

Neal Stewart, professor of plant molecular genetics at the University of Tennessee in Knoxville, who testified before the Royal Commission about the safety of genetically modified crops, calls Conner's switch "a brilliant move."

"It's a very Kiwi thing to do," he says. "They tweak what seems to be an existing constraint and wind up doing an end around."

Conner's end around could find traction with the public. Surveys performed by Bruce Small, a senior scientist in the social research unit of AgResearch in Hamilton, New Zealand, found that $58 \%$ of respondents agreed that gene transfer within species was acceptable.

That doesn't mean opposition to genetic modification has melted away (the same survey found that about 19\% disagreed with intraspecies gene transfer, and 25\% felt that cross-species gene transfer was acceptable), and Claire Bleakley, president of the non-profit group GE Free New Zealand, isn't backing Conner. "He heard a public concern," she says, "but instead of going into something like marker-assisted natural breeding, he has gone on, I believe, to subvert the process of genetic engineering to make

Arguments over
genetically modified
crops cannot be won
"by just using science,"
says Conner.

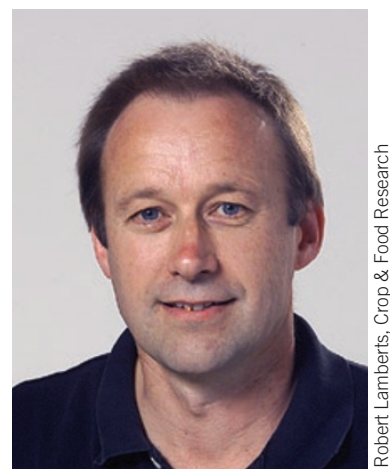

it look much [more acceptable]."

He's also faced criticism from the other side: many of his fellow scientists claim he is lying down and allowing the science of genetic engineering to be eviscerated. One of his colleagues was verbally attacked at a meeting, he says, and about half of his papers are rejected in peer review because of a philosophical objection to his approach. "It's been a hard battle scientifically," he says.

Conner plans to use species-specific promoters to change the expression patterns of genes, but he concedes that intragenics must first prove its mettle in the field. Conner expects to grow colored tubers and disease-resistant potatoes in the laboratory this year, and then he will consider applying for field trials. Politicians and the public could present a more difficult hurdle. "I think the jury is still out, but [intragenics] might appeal to politicians and [nongovernmental organizations] who are of a more moderate ilk," says Stewart.

For Conner, science should reflect the goals of the public. "People have these deeply held moral and ethical views [about genes switching species]," and they "don't tend to move on those positions," he says. The goal shouldn't be to change their minds, but to remove ethics from the equation and reduce the issue to "a scientific debate about safety."

Jim Kling, Bellingham, Washington 


\section{Erratum: Tony Conner}

\section{Jim Kling}

Nat. Biotechnol. 26, 259, 2008; published online March 2008; corrected after print 6 June 2008

In the version of this article initially published online, in paragraph 7, beginning with line 2, the author incorrectly stated that "genes and promoters" were to be used; the line should have read "DNA sequences." Also, beginning with line 6, author did not include the terms "with their natural promoters, terminators and introns," between the words "species-specific genes" and "are transferred between." Finally, also beginning on line 6 , the author incorrectly used the terms "but use promoters from bacteria or other organisms." The line should have read "using standard vectors based on foreign DNA.” The errors have been corrected for all versions of the article. 